\title{
NOTICES OF BOOKS
}

Indian Thought, Past and Present. By R. W. Frazer, LL.B., C.E., I.C.S. (Ret.). London, 1915.

In this work Mr. Frazer aims at giving a clear and connected account of the thought of India in its relation to the social and religious situation of India to-day. It is his aim to present the history of that thought at once concisely and objectively, and in the attempt he has been well served by his extensive study not merely of the literature bearing directly on the history of Indian religion and philosophy but also of the general literature of philosophy; and his extensive acquaintance with Tamil literature has enabled him, especially in the sections of his work dealing with Śaivism and Viṣnuism, to contribute matter of special interest. The mode of exposition chosen is excellent : it discards the formalities of each system, and confines itself to the essential doctrines, a method of procedure which is much more attractive and practical than any effort to expound a system in its native setting, and which is fully justified by the aim of the work. At the same time the different expositions of the several philosophies which have been set out are frankly recognized: Mrs. Rhys Davids' idealistic view ${ }^{1}$ of Buddhism is treated as impartially as the more subdued enthusiasm of Oldenberg or Oltramare. The treatment of the subject is, though brief, comprehensive: the Vedas, Brāhmaṇas, Upaniṣads, Vedānta, Sāmkhya, Vaiśeșika and Nyäya, Yoga, Buddhism, and Hinduism are dealt with in succession, and a chapter on the position of women in India precedes an account of the movements in modern Indian thought seen in the Ádi Samāj and its offshoots. 
The chapter regarding Indian conceptions of the duty of women seems at first a little incongruous in its setting, but the obvious explanation of its presence is that it rectifies the grave defect of all the philosophical systems of India of the period before the last century : in their disregard of ethical problems and in their excessive intellectualism these philosophies had no occasion seriously to study the position of woman in the universe, and Sankara, who is after all the greatest of Indian philosophers, refused to allow the study of the Vedanta to women, a view in which he was plainly and undeniably in full accord with the general tendency of Indian thought, despite the grudging concessions made by Buddhism and Jainism. With his wonted impartiality the author is careful to present the best side of the Indian ideal of women : he allows Dr. Coomaraswamy ${ }^{1}$ to point out the ideal of Sati, and almost to say that the Native States are ruled by the queen-mothers from behind the Purdah, without pointing out that the last-mentioned fact may, in consequence of the ignorance and incapacity of women who have been brought up under the Purdah system, explain the fact that the Native States are much less well ruled than British India. Sir Lepel Griffin ${ }^{2}$ is also allowed to express opinions on the comparative social and legal position of married Muhammadan women which suggest that he was imperfectly acquainted with either the English law of property and status or with the Muhammadan law on the same subjects, or with both. But the author provides ample evidence to counterbalance these assertions by the simple record from the census report of $1913{ }^{3}$, that only ten females in a thousand were then able to read or write a simple letter, while the number in the case of men was 106. The same judicial impartiality displays itself in the treatment of the modern developments of Indian thought: due regard

$$
{ }^{1} \text { pp. 303, 304. } \quad 2 \text { p. } 292 . \quad 3 \text { p. } 302 .
$$


is given to the effect of Dayānanda's teaching, though the author is perfectly aware that his interpretation of the Veda is a monstrosity to which no value whatever can be attached, and that in so far as the teaching rests on this view of the Veda it is fundamentally unsound. ${ }^{1}$

Mr. Frazer everywhere shows his readiness to balance opposing views: he sets out quite fairly the evidence regarding the position of Krṣna and the possibility of the relation of the Krṣna cult to Christianity, and if he assigns more weight to some of the evidence adduced for the early presence of Christian teaching than Garbe does, that is matter for legitimate difference of opinion. ${ }^{2}$ It is more doubtful whether the acceptance of the view ${ }^{3}$ that Väsudeva was a Kṣatriya born about the fourth or the third century B.c. can be taken as legitimate: if he were a real man born at that date it is curious in the extreme that we have so little evidence regarding him of the historical type which makes us feel the reality as men of the Buddha and of Mahāvira, despite all the mythology which has sprung up around them. Mr. Frazer doubtless can claim the high authority of Bhandarkar for the historical reality of Vasudeva, but on this point it seems clear to me that Sir R. G. Bhandarkar is distinctly wrong.

Special interest attaches to Mr. Frazer's examination of the problem presented by the Upanisads and Sankara, and his views on these questions are clearly and effectively expressed. He does not directly deal with the theory which Jacobi ${ }^{4}$ patronized that the doctrine of Māya owed its acceptance to the nihilism and the Vijñāna doctrines of the Buddhist schools, but he would probably agree with de la Vallée Poussin, ${ }^{5}$ whose comparison of Nāgārjuna and Sañkara he quotes ${ }^{6}$ in another 
connexion with just approval, that the two doctrines have an essential basis of difference. Sankara he treats sympathetically, and even points out that his view of time and space, apart from the question of final reality, has closer affinities to some streams of modern thought than the view of Kant: perhaps more stress might have been laid on the fact that the Kantian doctrine, while denying that things in themselves can be subjects of our knowledge, yet does not assert in any sense the unreality of the world, and that in the sphere of ethics Kant finds a doctrine which supplies us with a positive moral law, and gives a real meaning to life. The doctrine of Sankara, on the other hand, is fatally handicapped in dealing with any question of ethic. On the one hand, in the highest sense ethical action has no existence and no meaning; in the other there can be no criterion of good or bad, since all is equally derived from the Māya of the Íśara. The Kantian philosophy is very imperfect and unsatisfactory, but in a far less degree than that of Sankara, apart from the grave defect that Sankara argues from the holy scriptures, and not from a logical basis.

Some minor points will doubtless be reconsidered in a later edition. The derivation of putra (p. 273) is from put, not $p u$, the etymologists taking advantage of the spelling with double $t$ before $r$. The account of the practice of widow-burning (p. 279) is unduly lenient on the older practice, which undoubtedly contemplated burning, but merely as a usage which was out of date, the wife being made to rise from the side of the dead, in place of fulfilling the ancient practice and dying with her husband, and it attaches undue importance to the alteration of agre to agneh in the funeral hymn of the Rgveda, ${ }^{1}$ which was only apparently made at quite a late date and rather as a result of

\footnotetext{
1 x, 18. 7. See FitzEdward Hall, JRAS. N.s. iii, 183-92.
} 
the practice of widow-burning than as a cause of it. The assignment (p. 284) of Brhaspati to the sixth or seventh century B.C. is a slip: his date is rather about 600 A.D., nor can Ápastamba in my opinion be placed much before 300 B.c. and he may perhaps be as late as about 250 B.c. The doctrine (p. 286) that the place played by the wife of Yàjñavalkya in the Upanișad of the White Yajurveda is due to the free thought of Ksatriyas, embodies a doctrine which seems to me to be wholly wrong, despite the considerable body of opinion in its favour: at any rate, in this case it is remarkable that the person whose wife is concerned should be the chief ritual authority of the first part of the Satapatha Brāhmana. The free thought of Kṣatriyas as regards the treatment of women is also hardly consistent with the picture of the position of women presented in the epic, where we find in some passages clear traces of something very like the Zenana system, though other passages present a different condition of affairs: in any case the reference at p. 290 to the introduction of this system through Muhammadan influence must be modified in emphasis.

There is an obvious slip in the date of Tirumūlar on p. 267, and on p. 109 it might be well to remember that there is some evidence ${ }^{1}$ against the identification of the Sankara of the comment on the work of Gaudapada and him of the Bhōsya.

A. Berriedale Keith.

Introduction to the Study of Indian Music. By E. Clements. (Foreword by A. K. Coomaraswamy.) pp. ix, 104. London: Longmans, Green, \& Co., 1913. The sub-title of this work is, "An attempt to reconcile modern Hindustani music with ancient musical theory,

${ }^{1}$ Cf. Jacobi, JAOS. xxxiii, 52, n. 2. 